2016-05

\title{
We the living: the effects of living and deceased donor stories on charitable bequest giving intentions
}

\section{James, RN}

http://hdl.handle.net/10026.1/8449

\subsection{2/nvsm.1549 \\ International Journal of Nonprofit and Voluntary Sector Marketing}

All content in PEARL is protected by copyright law. Author manuscripts are made available in accordance with publisher policies. Please cite only the published version using the details provided on the item record or document. In the absence of an open licence (e.g. Creative Commons), permissions for further reuse of content should be sought from the publisher or author. 


\title{
We the living: the effects of living and deceased donor stories on charitable bequest giving intentions
}

\author{
Russell N. James III ${ }^{1,2 *}$ and Claire Routley ${ }^{2}$ \\ ${ }^{1}$ Texas Tech University, Personal Financial Planning, USA \\ ${ }^{2}$ Plymouth University, Centre for Sustainable Philanthropy, $U K$
}

Choosing messages to encourage charitable bequest giving may be particularly challenging given sensitivity to personal mortality reminders. Previous research suggests that people often react to mortality reminders with avoidance, including distancing themselves from those associated with death. We compare the effects of otherwise similar living and deceased bequest donor stories on subsequent intentions to leave a charitable bequest. Although both story types significantly increased subsequent intentions to leave a charitable bequest, living donor stories consistently outperformed otherwise identical deceased donor stories. Fundraisers may do well to emphasize stories of living planned bequest donors and deemphasize death and the deceased in charitable bequest fundraising messaging. Copyright (C) 2016John Wiley \& Sons, Ltd.

Keywords: charitable bequest, fundraising, philanthropy, planned giving

Charitable bequest giving is a significant source of income for many nonprofit organizations. In the USA, charitable bequest giving generated over \$28bn, exceeding all giving by corporations (Giving USA, 2015). Many large charitable organizations in the UK receive more than half of their charitable giving through bequest gifts (Pharoah, 2010).

Despite this magnitude, the potential for such giving is dramatically larger. Roughly 70 to $80 \%$ of

\footnotetext{
*Correspondence to: Russell N. James, Texas Tech University, Personal Financial Planning, Box 41210, Lubbock, Texas 79409, USA.

E-mail: russell.james@ttu.edu
}

the US population engages in current charitable giving (Giving USA, 2011), but fewer than 6\% leave charitable bequests at death (James, 2009). Similarly, only about one in ten substantial current donors (\$500 or more annually) will leave a charitable bequest at death (James, 2009). The magnitude of this difference between current and bequest giving rates suggests the substantial economic potential of any messages that could make charitable bequests as attractive as current charitable giving. Further, the importance of bequest giving will likely grow substantially in the coming years as the population continues to age (James, 2015c). 


\section{Literature review}

\section{Mortality salience and avoidance}

Previous research demonstrates the enormous difference between the share of those who participate in current charitable giving and charitable bequest giving (Atkinson, Backus, and Micklewright, 2009; Baker, 2014; James, 2009). What might explain this dramatic behavioral difference? Certainly, the motivations to leave charitable bequests can differ from those for current giving and often emphasize the central role of family in bequest decisions (Routley and Sargeant, 2014; Sargeant, Hilton, and Wymer, 2006a; Sargeant and Shang, 2011).

One distinction between bequest giving and current giving is that bequest transfers occur only at one's own death. Correspondingly, bequest giving decisions may be more likely to generate personal mortality contemplation. In their dual process model of death-related thoughts, Pyszczynski, Greenberg, \& Solomon (1999) explain that the initial defense against conscious thoughts of one's own death is to avoid, remove or postpone the death-related thoughts. This avoidance process has been observed in experiments where mortality salience can lead to, for example, actively suppressing death concerns, distraction or denial of one's vulnerability (Arndt et al., 1997; Greenberg et al., 2000). Thus, it is possible that avoidance of charitable bequest giving (as compared with current charitable giving) is related to the avoidance response to personal mortality contemplation.

To the extent that charitable bequest-related marketing messages could downplay the emphasis on personal mortality, it might reduce this natural avoidance response. James (2015a) found some evidence of this connection. In that experiment, respondents were significantly less likely to express interest in "make a gift to charity in my last will and testament that will take effect at my death," than in simply "make a gift to charity in my last will and testament" (James, 2015a). The addition of the gratuitous reference to the respondent's death as part of describing the charitable bequest gift had a negative effect on interest.
Personal mortality contemplation (such as that likely experienced in the typical bequest planning process) may also generate a more intense desire to distance oneself from those associated with death or bodily infirmity (Hirschberger, 2010). For example, mortality salience can lead to more negative evaluations of a person seated in a wheel chair (Ben-Naim, Aviv, and Hirschberger, 2008), increased avoidance of viewing photographs of physically injured people (Hirschberger et al., 2010), increased attribution of blame toward significantly injured victims as compared with mildly injured victims (Hirschberger, 2006), and a reduction of compassion for those with physical disabilities (Hirschberger, Florian, and Mikulincer, 2005). A desire to differentiate oneself from deceased bequest donor examples might reduce the effectiveness of these examples, relative to the living donor examples.

\section{Charitable bequests}

Much previous work on charitable bequest giving has focused on tax policy (Joulfaian, 2000; Barthold and Plotnick, 1984) and demographic correlates such as age, gender, education, wealth, and childlessness (James, 2009; Atkinson et al., 2009; Sargeant et al., 2006a; Chang, Okunade, and Kumar, 1999). Relatively less work has explored charitable bequest giving motivations. Of course, by researching tax policy, several have thereby explored the motivational effects of estate tax deductibility (e.g. Joulfaian, 2000). Others have more directly explored charitable bequest giving motivation. Sargeant \& Shang (2011) conducted ten focus groups, and Sargeant et al. (2006a) conducted eight focus groups with planned charitable bequest donors to uncover their charitable bequest giving motivations. Similarly, Routley \& Sargeant (2014) conducted interviews with 20 planned charitable bequest donors. Sargeant, Wymer, \& Hilton (2006b) surveyed bequest gift pledgers and contrasted their attitudes and demographics with 
other donor responses. Pike, Knott, \& Newton (2012) interviewed five industry experts and 12 alumni from an Australian university regarding their opinions on the topic of charitable bequest motivations.

Demographic correlates and inquiries into planned bequest donors' expressed motivations are valuable in deepening understanding in this topic. However, the kind of experimental testing of messages and approaches common in other charitable giving research (Bekkers and Wiepking, 2011; List and Lucking-Reiley, 2002) has been less common in studies of charitable bequest giving. Recent exceptions include a field experiment by Sanders, Halpern, \& Service (2013) and survey experiments by James (2015a, 2015b).

\section{Hypotbesis}

Consistent with an avoidance response to mortality salience, we propose the following:

Hypothesis: Otherwise, similar deceased bequest donor stories will be less effective than living bequest donor stories at increasing interest in making a charitable bequest gift.

\section{Metbodology}

\section{Participants}

In total, 2518 respondents completed an online survey hosted on the Qualtrics platform. Participants were US residents paid \$1 via Amazon.com's Mturk platform. Participants recruited in this way have been found in other contexts to generate experimental results similar to those conducted using more traditional samples in a face-to-face context (Casler, Bickel, and Hackett, 2013).

In order to insure that participants were paying close attention to the questions, only participants who first correctly followed detailed instructions in a preliminary question were permitted to complete the survey. Approximately one third of all those who attempted participation were excluded because of a failure to read and follow this initial instruction set.

Of respondents, $61.8 \%$ were female and $46.6 \%$ had a bachelor's degree or higher. Age information was collected in decades (e.g. 40s, 50s, etc.), and the median age category was the 30s. Because of the particular importance of the bequest decision making of older adults (James and Baker, 2015), the statistical analysis includes separate interactions to examine the difference in effects of the messages on those aged 50 and above.

\section{Procedure}

To establish initial levels of interest in current charitable giving, all participants answered with regard to 40 large national charities, ${ }^{1}$ "If you were asked in the next 3 months, what is the likelihood that you might GIVE money to each of the following organizations?" Responses used a 100-point scale described as "O-absolutely no possibility under any circumstance, 10-extremely bighly unlikely, 20-bighly unlikely, 30-somewhat unlikely, 40 - slightly more unlikely than likely, 50-50-50 chance, 60-slightly more likely than unlikely, 70 -somewhat likely, 80-bighly likely, 90-

\footnotetext{
${ }^{1}$ The American Cancer Society, National Audubon Society, The American Society for the Prevention of Cruelty to Animals, San Francisco AIDS Foundation, Breast Cancer Research Foundation, Foundation Fighting Blindness, Boys and Girls Clubs of America, CARE, YWCA, The Alzheimer's Foundation of America, Dana Farber Cancer Institute, Wildlife Conservation Society, Guide Dogs for the Blind, American Indian College Fund, Habitat for Humanity, American Lung Association, Boy Scouts, The United Way, The Salvation Army, Joslin Diabetes Center. National Cancer Coalition, Ducks Unlimited, The American Humane Association, AIDS Project Los Angeles, National Breast Cancer Foundation, Prevent Blindness America, Big Brothers/Big Sisters of America, UNICEF, YMCA, The Alzheimer's Association, MD Anderson Cancer Center, World Wildlife Fund, Canine Companions for Independence, United Negro College Fund, Susan G. Komen Breast Cancer Foundation, The American Heart Association, Girl Scouts, Goodwill Industries, The American Red Cross, The American Diabetes Association.
} 
extremely bighly likely, 100-absolutely certain without any possible doubt."

Participants not in the control group then read four bequest donor stories. The stories were either in a living or a deceased donor version but were otherwise identical. They next rated their bequest intentions ("If you signed a will in the next 3 months, what is the likelihood you might leave a BEQUEST gift to each of the following organizations?") for 20 of the large national charitable organizations using the same 100-point scale. They then read an additional three donor stories in either a living or deceased version. Finally, they rated their bequest intentions regarding the remaining 20 large national charitable organizations.

Participants in the control group answered the same questions about bequest intentions but did not read any donor stories. Thus, prior to rating their bequest intentions, participants may have been exposed to (1) no donor stories, (2) four deceased donor stories, (3) four otherwise identical living donor stories, (4) seven deceased donor stories, (5) seven otherwise identical living donor stories, or (6) seven stories consisting of three or four deceased donor stories and three or four living donor stories. Assignment to groups was random, although more total respondents were assigned to the story groups.

All participants initially answered a similar set of questions. These included providing demographic information, demonstrating an understanding of the terms "bequest," "will," "last will and testament," and "estate" and answering four questions about preferences regarding treatment of their body after death (in order to induce heightened mortality salience as might be expected in an actual estate planning context).

\section{Deceased bequest donor stories}

There were seven vignettes of donors' life stories and their subsequent charitable bequests. The text of the vignettes was used with permission from the "Leave a Legacy" public awareness campaign and can be found at http://www.leavealegacy.org/ MediaCenter/media_posters.asp

\section{Living bequest donor stories}

These were otherwise identical to the deceased bequest donor stories, except they referred to the donor as living (rather than deceased) and the bequest as planned (rather than completed). For example, the deceased donor story beginning, "School janitor Lester Holmes died in 1992. After school today he'll help...," became "School janitor Lester Holmes signed his will today. One day, his charitable bequest gift will help..." with subsequent text placed in the future tense.

All donor stories were presented with images consisting of a framed photograph of the purported bequest donor placed on a table or wall in a domestic setting. Identical images were used for both the living and deceased donor stories. In order to include diverse donor examples, the seven donor images included four males and three females. Three pictured donors were white, two were black, and two were Asian. To increase attention to the donor stories, following each story, respondents were asked a question about the content of the story.

\section{Results}

Table 1 shows the average initial (pre-story) interest in a current gift and the subsequent (post-story) interest in a bequest gift measured for each of the 40 large national charities. All groups exposed to bequest donor stories reported significantly greater interest in making a bequest gift, relative to their initial interest in making a current gift, than did the control group. Living donor stories were consistently more effective than deceased donor stories at increasing the relative interest in making a bequest gift. The first four living donor stories (row e) were significantly more effective than the deceased version of the same stories (row b). The same was true when comparing the two versions of all seven stories (row g vs. row c). Adding three 
Table 1. Charitable bequest intentions with differing story types

$\begin{array}{lll}\text { (a) None } & 26.28 & 15.89 \\ \text { (b) Four deceased only } & 25.48 & 19.08 \\ \text { (c) Four deceased + three deceased } & 26.56 & 19.97 \\ \text { (d) Four deceased + three living } & 25.40 & 19.87 \\ \text { (e) Four living only } & 28.22 & 22.58 \\ \text { (f) Four living + three deceased } & 27.06 & 20.40 \\ \text { (g) Four living + three living } & 26.42 & 22.41\end{array}$

Statistical significance references a $t$-test comparison between the giving intent less bequest intent difference in each row versus the giving intent less bequest intent difference in the referenced comparison row $(a, b$, or e). The difference in each of rows b-g was smaller than the difference in the control group (row a) at $p<0.001$. ns, not statistically significant at $p<0.05$. ${ }^{*} p<0.005$. *** $p<0.01$. **** $p<0.001$.

living donor stories to the initial four stories (either living or deceased) significantly increased relative interest in a bequest gift, but adding the deceased version of these three stories reduced this relative interest. (Although not reported in the table, there were no individual charities among the 40 tested for whom living donor stories did not generate relatively more positive results than deceased donor stories.)

As a check on any possible negative effects of the living donor stories on current giving intentions, 325 respondents were asked to re-rate their current giving intentions, rather than rate their bequest giving intentions, after reading the first four living bequest donor stories. The average current giving intention rose by 0.50 points suggesting that there was no negative spillover on current giving intentions from the living donor stories.

Table 2 shows regression results where the intention to make a bequest gift is the dependent variable. Each bequest intention for each organization constitutes a separate observation. The initial (premessage) current giving intention for the organization is included as a control in all regressions making the analysis framework conceptually similar to the differences reported in Table 1.

The first regression shows results from an ordinary least squares (OLS) analysis with no controls where all observations are treated as independent.
The results are consistent with the cross-tabulations, with living donor stories generating more interest in bequest gifts than otherwise similar deceased donor stories for both the initial four stories and the additional three stories.

An OLS regression assumes that the observations are independent. However, in this case, each respondent rated multiple organizations. Ratings from the same person are likely to be correlated, thus violating the OLS assumptions. To adjust for this, the second regression fits the marginal generalized estimating equations (GEE) regression model using PROC GENMOD in SAS (Johnston and Strokes, 1997) where all responses from each separate respondent are treated as a separate cluster. Additionally, this regression adds controls for age (coded as 1 for under 25, 2 for 25-29, 3 for 30-39, 4 for 40-49, 5 for 50-59, 6 for 60 and above), education (coded as 1 for less than high school, 2 for high school, 3 for some college, 4 for associates degree, 5 for bachelor's degree, 6 for master's degree, 7 for doctoral degree), gender, and individual dummy variables representing each of the 40 different charities (coefficients not reported). Most results from the first regression remain roughly similar in the second although with reduced statistical significance.

Regression 3 examines interaction effects. This is intended to address the question of whether living or deceased donor story types are significantly more 
Table 2. Regression analysis of bequest giving intentions

(1) OLS (2) Clustered GEE with controls

$$
\begin{gathered}
3.859(0.751)^{* * * *} \\
-0.726(0.377) \\
5.152(0.713)^{* * * *} \\
0.99(0.362)^{* *} \\
0.68(0.011)^{* * * *} \\
-0.5(0.179)^{* * *} \\
-0.467(0.186)^{* *} \\
-1.016(0.526)
\end{gathered}
$$

Female

InitialDeceased"Female

EndingDeceased*Female

InitialLiving*Female

EndingLiving*Female

Age 50+

InitialDeceased*Age 50

InitialDeceased*College

InitialLiving*Age 50

EndingLiving*Age 50

College (bachelor's+)

EndingDeceased*Age 50

EndingDeceased*College

InitialLiving*College

EndingLiving*College

Intercept

Organization dummies $n$
$0.987(0.162)^{* * * * *}$

$0.681(0.002)^{* * * * *}$

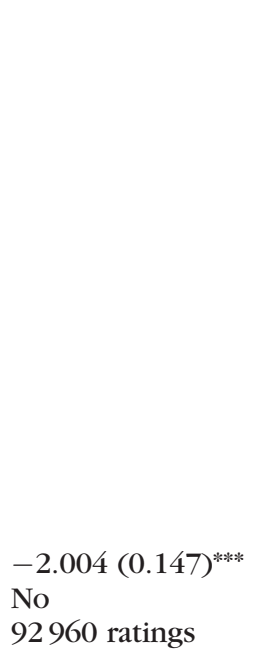

(3) Clustered GEE with interactions

Dependent variable is respondents' reported intention to make a bequest gift (100-point scale) for each charity. ${ }^{*} p<0.05$. ${ }^{* *} p<0.01$. ****: $p<0.001$.

or less effective for certain groups defined by gender (female), age (50+), and education (bachelor's degree or above). There were no significant interaction effects except that the initial deceased donor stories were less effective for men than for women, and the initial living donor stories were more effective for older adults $(50+)$ than for younger adults.

The coefficients for the living donor stories were greater than those of the deceased donor stories. To test for the significance of this difference, in an unreported regression, the omitted comparison group was changed from the control group (no message) to the group receiving the initial four deceased stories. In these regressions, the coefficients for receiving the initial four living stories (contrasted with the initial four deceased stories) were $1.408(\phi<0.0001)$ in the OLS regression, $1.390 \quad(p=0.0174)$ in the controlled GEE regression, and $2.175(\phi=0.0247)$ in the controlled GEE with interactions. Thus, the regressions confirm the results from the descriptive statistics.

\section{Discussion}

Both living and deceased bequest donor stories increased the relative likelihood of making a charitable bequest gift as compared with receiving no stories. These stories may be effective by providing examples that set a social norm encouraging such gifts. Previous research indicates that the use of a social norm statement during the estate planning process ("many of our customers like to leave money to charity in their will. Are there any causes you're 
passionate about?") increased participation in charitable bequest giving (Sanders et al., 2013). Similarly, James (2015a) found that adding a social norm statement ("many people like to leave a gift to charity in their wills") to the description of a charitable bequest gift significantly increased interest in making such a gift. The current results suggest a similarly positive effect from sharing stories of others who have made such gifts. The use of social norms such as these may be particularly impactful for estate giving decisions considering that previous research in terror management theory suggests that mortality salience increases the desire to support social norms (Pyszczynski et al., 1999).

However, otherwise identical living donor stories were clearly superior to deceased donor stories in increasing bequest giving intentions. The idea that norm adherence is dependent upon perceived similarity with the example actor is relatively well established in psychological research (Festinger, 1954; Moschis, 1976) and may partly explain why our results show that more stories are more effective, with more stories offering more opportunity for perceived similarity. In the case of the living examples, the living bequest donor is more similar to the respondent than is the otherwise identical deceased donor, simply by virtue of being alive. This one difference may be particularly powerful given previous research suggesting that personal mortality contemplation (such as making end-of-life distribution choices) may generate a more intense desire to distance oneself from those associated with death or bodily infirmity. More broadly, this provides additional evidence on the benefits of de-emphasizing a focus on death in charitable bequest fundraising messaging.

\section{Implications for professional practice}

For the fundraiser, the most practical consequence of this study is that (a) sharing stories appears to increase bequest intentions and (b) concentrating on living donor stories appears more effective. However, in order to tell these stories and to tell multiple stories over time and across channels, fundraisers would need to introduce mechanisms for collecting, storing, and managing donor stories. Some organizations, which take a direct marketing-led approach, now include the facility within their appeals for donors to share their stories, rather than purely ticking a box to indicate their bequest intention. For others, where there is more one-to-one interaction, fundraisers could encourage colleagues to collect donor stories at their meetings or via the telephone. Our results tested the use of a variety of different stories; fundraisers could make a conscious effort to capture stories from people of different demographic backgrounds and perhaps with different motives for supporting that charity.

Although collecting stories may sound like a simple idea, embedding the process of capturing stories with the requisite level of detail, ensuring that those stories can be stored appropriately and utilized when necessary may involve developing new processes, shared across several fundraising teams. There is potentially a wide application for stories in legacy fundraising practice, from case studies in direct marketing material, to stories shared at events, to newsletter features. Digital media offers a particularly exciting space to share stories: for example, by using video to bring donor stories to life.

Future research in a more naturalistic setting, with an audience selected for their legacy potential and testing various mechanisms of sharing stories, would be a valuable addition to knowledge in this area. In the meantime, charities may wish to test the potential for this message type in their own contexts.

\section{Biographical notes}

Dr. Russell James III is a professor at Texas Tech University where he directs the on-campus and online graduate program in charitable financial planning. $\mathrm{He}$ is also a visiting research professor at Plymouth University's Centre for Sustainable Philanthropy. Prior to his academic research career he practiced 
as an estate planning attorney and director of planned giving for Central Christian College, where he later served as college president.

Dr. Claire Routley has worked in fundraising for fourteen years, specialising in legacy fundraising for the last ten. In 2011, she completed a PhD looking at why people choose to leave legacies to charity. She has worked for Bible Society, Age UK, WRVS and a local hospice, and is a tutor for the Institute of Fundraising's qualification courses. She is now a fundraising consultant, and a research fellow at Plymouth University's Centre for Sustainable Philanthropy.

\section{References}

Atkinson AB, Backus PG, Micklewright J. 2009. Charitable bequests and wealth at death in Great Britain. Retrieved from http://eprints.soton.ac.uk/65909/1/ 65909-01.pdf (accessed on Sept. 5, 2015).

Arndt J, Greenberg J, Solomon S, Pyszczynski T, Simon L. 1997. Suppression, accessibility of death-related thoughts, and cultural worldview defense: exploring the psychodynamics of terror management. Journal of Personality and Social Psychology 73: 5-18.

Baker C. 2014. Encouraging charitable bequests by Australians. Swinburne University of Technology, Asia-Pacific Centre for Social Investment Philanthropy: Melbourne, Australia accessed on July 29, 2014.

Barthold T, Plotnick R. 1984. Estate taxation and other determinants of charitable bequests. National Tax Journal 37: 225-237.

Bekkers R, Wiepking P. 2011. A literature review of empirical studies of philanthropy: eight mechanisms that drive charitable giving. Nonprofit and Voluntary Sector Quarterly 40(5): 924-973.

Ben-Naim S, Aviv G, Hirschberger G. 2008. Strained interaction: evidence that interpersonal contact moderates death-disability rejection link. Rebabilitation Psychology 53(4): 464-470.

Casler K, Bickel L, Hackett E. 2013. Separate but equal? A comparison of participants and data gathered via Amazon's Mturk, social media, and face-to-face behavioral testing. Computers in Human Bebavior 29(6): 2156-2160.

Chang CF, Okunade AA, Kumar N. 1999. Motives behind charitable bequests. Journal of Nonprofit Public Sector Marketing 6(4): 69-85.

Festinger L. 1954. A theory of social comparison processes. Human Relations 7: 117-140.

Giving USA. 2011. Giving USA: The Annual Report on Philanthropy 2011. The Center on Philanthropy at Indiana University: Indianapolis, IN.

Giving USA. 2015. Giving USA: The Annual Report on Philanthropy 2014. The Center on Philanthropy at Indiana University: Indianapolis, IN.

Greenberg J, Arndt J, Simon L, Pyszczynski T, Solomon S. 2000. Proximal and distal defenses in response to reminders of one's mortality: evidence of a temporal sequence. Personality and Social Psychology Bulletin 26: 91-99.

Hirschberger G. 2006. Terror management and attributions of blame to innocent victims: reconciling compassionate and defensive responses. Journal of Personality and Social Psychology 91: 832-844.

Hirschberger G. 2010. Compassionate callousness: a terror management perspective on prosocial behavior. In Prosocial motives, emotions, and behaviors: the better angels of our nature, Mikulincer M, Shaver PR (eds). American Psychological Association: Washington, DC; 201-219.

Hirschberger G, Ein-Dor T, Caspi A, Arzouan Y, Zivotofsky AZ. 2010. Looking away from death: defensive attention as a form of terror management. Journal of Experimental Social Psychology 46(1): 172-178.

Hirschberger G, Florian V, Mikulincer M. 2005. Fear and compassion: a terror management analysis of emotional reactions to physical disability. Rebabilitation Psychology 50: 246-257.

James RN, III. 2009. Health, wealth, and charitable estate planning: a longitudinal examination of testamentary charitable giving plans. Nonprofit and Voluntary Sector Quarterly 38(6): 1026-1043.

James RN, III. 2015a. Phrasing the charitable bequest inquiry. Voluntas, Advance online publication. DOI:10.1007/s11266-015-9556-4.

James RN, III. 2015b. The family tribute in charitable bequest giving. Nonprofit Management Leadership 26(1): 73-89. 
James RN, III. 2015c. The new statistics of estate planning: lifetime and post-mortem wills, trusts, and charitable planning. Estate Planning \& Community Property Law Journal 8(1): 1-39.

James RN, III, Baker C. 2015. The timing of final charitable bequest decisions. International Journal of Nonprofit and Voluntary Sector Marketing 20: 277-283.

Johnston G, Strokes M. 1997. Application of GEE methodology using the SAS system. NorthEast SAS Users Group. http://www.nesug.org/Proceedings/nesug97/ stat/stokes.pdf (accessed on July 29, 2014).

Joulfaian D. 2000. Estate taxes and charitable bequests by the wealthy. National Tax Journal 53(3): 743-763.

List J, Lucking-Reiley D. 2002. The effects of seed money and refunds on charitable giving: experimental evidence from a university capital campaign. Journal of Political Economy 110(1): 215-233.

Moschis GP. 1976. Social comparison and informal group influence. Journal of Marketing Research 13: 237-44.

Pharoah C. 2010. Charity market monitor 2010: tracking the funding of UK charities. CaritasData: London.

Pike S, Knott K, Newton C. 2012. Perceptions of charities and the ultimate gift: the use of the Repertory Test to elicit salient bequest decision criteria. International Review of Public and Nonprofit Marketing 9: 19-136. Pyszczynski T, Greenberg J, Solomon S. 1999. A dual process model of defense against conscious and unconscious death-related thoughts: an extension of terror management theory. Psychological Review 106: 835-845.

Routley C, Sargeant A. 2014. Leaving a bequest: living on through charitable gifts. Nonprofit and Voluntary Sector Quarterly. Advance online publication. doi: $10.1177 / 0899764014542687$

Sanders M, Halpern D, Service O. 2013. Applying behavioral insights to charitable giving. Retrieved from http://www. behaviouralinsights.co.uk/sites/default/files/BIT_Charitable _Giving_Paper\%20(1).pdf (Accessed on Sept 5, 2015).

Sargeant A, Hilton T, Wymer W. 2006a. Bequest motive and barriers to giving: the case of direct mail donors. Nonprofit Management Leadership 17: 49-66.

Sargeant A, Shang J. 2011. Bequest giving: revisiting donor motivation with dimensional qualitative research. Psychology Marketing 28(10): 980-997.

Sargeant A, Wymer W, Hilton T. 2006b. Marketing bequest club membership: an exploratory study of legacy pledgers. Nonprofit and Voluntary Sector Quarterly 35(3): 384-404. 